\title{
Analysis of the Difficulty of Understanding Concepts and Creative Thinking of Students in Mathematics through Problem- Based Learning in Students of SMA Angkasa Lanud Soewondo
}

\author{
Riadi $^{1}$, Bornok Sinaga ${ }^{2}$, Edi Syahputra ${ }^{3}$ \\ ${ }^{1,2,3}$ Universitas Negeri Medan, Indonesia \\ riadimazz44@gmail.com,bsinaga@unimed.ac.id,edisyahputra01.es@gmail.com
}

\begin{abstract}
This study aims to determine the level of students' mathematical concept understanding and creative thinking skills who are taught using a problem-based learning model, to find out the description of the student's answer process in learning using a problem-based learning model, to determine the difficulties in the process of understanding concepts and mathematical creative thinking of students who are taught using problem-based learning models, as well as to find out the active activities of students during the learning process using problem-based learning models. Data were obtained through tests of students' conceptual understanding and creative thinking tests, interviews with students and teachers, observations or observations by observers, and documentation. This research uses qualitative data analysis using Miles and Huberman's model, namely data reduction, display data, and conclusion drawing / verification data. The subjects of this study involved class X SMA Angkasa 1 Lanud Soewondo who were treated with the application of a problem-based learning model in the odd semester of the 2020/2021 school year, totaling 21 people with three-variable linear equation system material as many as 4 items in essay form. Based on the results of the study, there were 21 students with 'very low' creative thinking skills and $14 \%$ 'very low' creative thinking skills, $14 \%$ 'low' creative thinking skills, $43 \%$ 'medium' creative thinking abilities, $43 \%$ thinking skills creative 'high' as much as $19 \%$, and 'very high' creative thinking ability as much as $10 \%$.
\end{abstract}

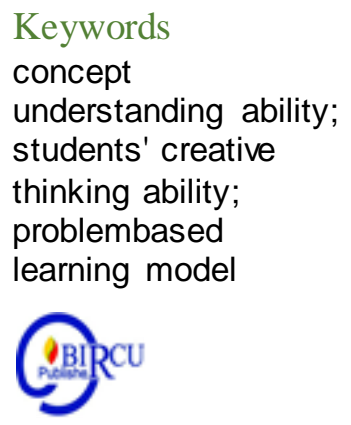

\section{Introduction}

One Mathematics is a part of education. Mathematics as a basic science, both its applied aspects and its reasoning aspects has an important role in the effort to master science and technology. There are many reasons for the need for students to learn mathematics, including a means of thinking clearly and logically, a means of solving problems in life, a means of recognizing patterns, a means of developing creativity and increasing awareness of culture (Cornelius, in Fahradina, 2014).

These five aspects are strong reasons for students to study mathematics in depth so that the expected abilities can be mastered and this coincides with an increase in human resources. Furthermore, the Directorate General of GTK, Ministry of Education and Culture (in Purba, 2017) states that things that need to be developed in learning mathematics are 1) mastery of mathematical concepts; 2) problem solving skills; 3) the ability to reason and communicate; 4) the ability to think creatively and innovatively. 
The Indonesian government has made various efforts to improve the quality of teaching and improve student mathematics learning outcomes, because mathematics is a very important science in every level of education pursued by every Indonesian citizen. The government's efforts include developing curricula, providing training to teachers, completing educational infrastructure and even improving teacher welfare. Along with the development of the internet, learning strategies have shifted and various information and communication technology-based learning strategies have emerged, from e-learning models, smart classroom technology, virtual classrooms, belded learning, etc. (Fitri \& Zahari, 2019).

Through good mathematics education, students can indeed obtain various kinds of provisions in facing challenges in the global era. In the 2013 curriculum itself, the use of technology in learning became something that was highly recommended. The learning process in the 2013 curriculum requires students to participate actively and provide sufficient space for students' creativity, interests, and talents (Fitri, Syahputra, \& Syahputra, 2019).

Based on the descriptions that have been put forward, it can be concluded that mathematical creative thinking is a thought process that produces a product (new ideas) in problem solving that can produce various possible answers or solutions. Indicators of creative thinking abilities used in this study are indicators of creative thinking in mathematics from silver which include fluency, flexibility, and novelty. Fluency is characterized by students being able to solve problems in various ways (at least two ways) to get the right answer. Flexibility is characterized by students being able to solve problems without strict rules or different ideas to get the right answer. Novelty is characterized by students being able to solve problems in their own way to get the right answer.

One of the causes of the low ability of understanding concepts and creative thinking in students' mathematics, including inaccuracy and less variation in the use of mathematics learning models and media used by teachers in class or it may be due to learning mathematics as monotonous and teacher-centered learning. In addition, learning mathematics in the classroom is not meaningful and does not emphasize student understanding, so that students' understanding of mathematical concepts is very weak. As stated by Sinaga (2007) that "The reality shows that so far most teachers use conventional learning models and many are dominated by teachers. At the time of learning mathematics the teacher often uses the lecture and question-and-answer method, resulting in students being unable to develop their knowledge".

This is in accordance with the results of observations and interviews with mathematics teachers at SMA Angkasa Lanud Soewondo Medan, where students often experience difficulties when learning mathematics. Mr. Dony Syafrizal as a mathematics teacher said that in the teaching and learning process, he often used the lecture, question-and-answer method, and gave regular assignments in the form of homework to students which resulted in students becoming listeners, listening, and paying attention then completing the assignments given by the teacher without being interaction to develop abilities in mathematics. Teachers also do not pay attention to student learning styles. When learning takes place, the learning style is not optimized so that students tend to find it difficult to understand what is conveyed by the teacher because the way of conveying information is not appropriate with the way students capture the information. The teacher also stated that they did not have much time to analyze the process of understanding concepts and students' creative thinking so that the teacher only gave routine questions during learning and without a detailed evaluation of the abilities in mathematics that students had to achieve including the ability to understand concepts and think creatively. 
Based on the above interviews, the teachers still apply the lecture and question-andanswer method learning, these results in the teacher not contributing in training students' creative thinking skills. So it is necessary to find other alternatives in improving the quality of mathematics learning, as well as paying attention to student learning styles. So a learning model is needed that gives students the opportunity to have good (student-centered) activities where the teacher becomes a motivator and facilitator. Also a learning model that is very supportive of student learning styles. Similarly, seeing the conditions of students who have difficulty understanding the material and students need learning media that can help improve student learning outcomes (Simanjuntak, 2019).

The choice of problem-based learning model is also based on the results of several studies showing that the ability to understand concepts and creative thinking in mathematics is still low compared to other models. One learning model that embraces constructivism is the problem based learning model (Imelda, 2019). As in the research of Rahmazatullaili (2017), "the increase in the value of the gain value of creative thinking in students' mathematics with the PjBL model is 0.64". Meanwhile, in Nurqobilbiah's research (2016), "the increase in the value of creative thinking gain in students' mathematics with the PBL model is 0.58". Based on the results of several studies above, there is still a low increase in the ability to understand concepts and think creatively in students' mathematics by using Problem Based Learning which allows students to learn in groups, socialize, and is able to generalize about the learning given by the teacher, so that the math problems given by the teacher towards students can be done well. PBL learning is a teaching approach that uses real-world problems as a context for students to learn critical thinking and problem-solving skills, as well as to acquire essential knowledge and concepts from subject matter (Nurhadi in Khairani, 2020). In addition, the Problem Based Learning model is one of the learning models directed in the application of the curriculum in Indonesia today. Based on the above problems, the researcher is interested in conducting research on "Analysis of the difficulty of understanding concepts and creative thinking of students in mathematics through problem-based learning in students of SMA Angkasa Lanud Soewondo".

\section{Research Methods}

The subjects in this study were students of class X SMA Angkasa 1 Lanud Soewondo who were treated with the application of problem-based learning models in the odd semester of the 2020/2021 school year, totaling 21 people. The object of this research is the ability to understand concepts and think creatively in mathematics of students who are given a problem-based learning model on the subject of a three-variable linear equation system. The object of this research was obtained from the test results of students' mathematical concept understanding and creative thinking abilities and through interviews. This research is categorized into descriptive qualitative research types. This type of research is qualitative, meaning that this type of research aims to describe the difficulties in the process of understanding the concept and creative thinking of students in the application of problembased learning models. The resulting data is in the form of words or utterances obtained from interviews and writings or numbers obtained from interviews. Based on the descriptive qualitative approach in this study, all facts, both written and oral, from human data sources that have been observed and other related documents that are described as they are, are then reviewed as concisely as possible to answer the problem. 


\section{Results and Discussion}

From the corrected test results, the students' mathematical creative thinking ability levels are presented.

Table 1. Levels of Students' Ability to Understand Concepts and Creative Thinking of Mathematics

\begin{tabular}{|c|l|c|c|c|}
\hline No & Value Interval & $\begin{array}{c}\text { The Number Of } \\
\text { Students }\end{array}$ & Percentage & $\begin{array}{c}\text { Assessment } \\
\text { Criteria }\end{array}$ \\
\hline 1 & $\begin{array}{l}0 \leq \text { SKBKM }< \\
50\end{array}$ & 3 & 14 & Very Low \\
\hline 2 & $\begin{array}{l}50 \leq \mathrm{SKBKM} \\
65\end{array}$ & 3 & 14 & Low \\
\hline 3 & $\begin{array}{l}65 \leq \mathrm{SKBKM}< \\
75\end{array}$ & 9 & 43 & Medium \\
\hline 4 & $\begin{array}{l}75 \leq \mathrm{SKBKM}< \\
85\end{array}$ & 4 & 19 & High \\
\hline 5 & $\begin{array}{l}85 \leq \mathrm{SKBKM} \leq \\
100\end{array}$ & 2 & 10 & Very High \\
\hline
\end{tabular}

Information: SKBKM = Score of Mathematical Creative Thinking Ability

The Based on the results of the students 'mathematical creative thinking ability test, it was obtained the level of students' mathematical concept understanding and creative thinking abilities which were spread over five levels. Of the 21 students, it turns out that the level of understanding of the concept of mathematical creative thinking in mediumability students has the highest proportion and is followed by students with very low abilities. The results of the study by Siswono (2004) state that the results of the data analysis of the problem posing assignments from each research group resulted indicate that they tend to be in the 'less creative' group, meaning that they fulfill one or two criteria of creative products, namely novelty, fluency or flexibility. .

So, the level of mathematical creative thinking ability of 21 students at SMA Angkasa 1 Lanud Soewondo with 'very low' ability was 14\%, 'low' ability was $14 \%$, 'medium' ability was $43 \%$, 'high' ability was $19 \%$., and $10 \%$ 'very high' ability.

Observation of student active activities is carried out by one observer in each meeting on learning that applies the problem-based learning model. Student activities are activities carried out by students during the learning process, including: listening to / paying attention to teacher / friend explanations, reading / understanding problems, solving problems / finding ways and answers to problems, communicating with teachers / friends, arguing / expressing opinions, drawing conclusions from a information.

This average percentage is obtained from the results for the total percentage of the average frequency of activity for each category with the number of meetings, namely 5 (five) times. The mean percentage of time used by students for each activity category in the table above is compared with the following criteria:

Table 2. Criteria for Achieving Ideal Time for Student Activities

\begin{tabular}{|c|l|l|l|l|l|}
\hline No. & \multicolumn{1}{|c|}{ Student Activities } & \multicolumn{1}{|l|}{ Ideal Time } & \multicolumn{1}{c|}{$\begin{array}{c}\text { PWI Tole rance } \\
\text { Interval }\end{array}$} & Criteria \\
\hline 1 & $\begin{array}{l}\text { Listening to / paying attention to } \\
\text { the teacher / friend's explanation. }\end{array}$ & $\begin{array}{l}25 \quad \% \quad \text { dari } \\
\text { WT }\end{array}$ & $20 \% \leq \mathrm{PWI} \leq 30 \%$ & $\begin{array}{c}\text { Three of } \\
1,2,3,\end{array}$ \\
\hline
\end{tabular}




\begin{tabular}{|c|l|l|l|c|}
\hline No. & \multicolumn{1}{|c|}{ Student Activities } & Ideal Time & \multicolumn{1}{|c|}{$\begin{array}{c}\text { PWI Tole rance } \\
\text { Interval }\end{array}$} & Criteria \\
\hline 2 & Read student books, worksheets. & $\begin{array}{l}15 \% \text { dari } \\
\text { WT }\end{array}$ & $10 \% \leq \mathrm{PWI} \leq 20 \%$ & $\begin{array}{c}4,5 \\
\text { must be } \\
\text { fulfilled } \\
\text { and } 3,4 \\
\text { must be } \\
\text { fulfilled }\end{array}$ \\
\hline 3 & $\begin{array}{l}\text { Take notes on teacher } \\
\text { explanations, take notes from } \\
\text { books or from friends, solve } \\
\text { problems on worksheets, } \\
\text { summarize group work. }\end{array}$ & $\begin{array}{l}30 \% \text { dari } \\
\text { WT }\end{array}$ & $25 \% \leq \mathrm{PWI} \leq 35 \%$ & \\
\hline 4 & $\begin{array}{l}\text { Discuss / ask questions between } \\
\text { students and friends, and between } \\
\text { students and teachers. }\end{array}$ & $\begin{array}{l}30 \% \text { dari } \\
\text { WT }\end{array}$ & $25 \% \leq \mathrm{PWI} \leq 35 \%$ \\
\hline 5 & $\begin{array}{l}\text { Doing something that is not } \\
\text { relevant to learning. }\end{array}$ & $0 \%$ dari WT & $0 \% \leq \mathrm{PWI} \leq 5 \%$ & \\
\hline
\end{tabular}

Description: (Sinaga, 2007)

PWI is the percentage of ideal time

WT is the time available at each meeting

The largest proportion of the time students spend during teaching and learning activities is taking notes on teacher explanations, taking notes from books or from friends, solving problems on the worksheets, summarizing group work, which is $29.6 \%$ of the time available for each meeting. The percentage of this activity time is between the lower and upper limits of the established ideal time tolerance interval, namely $25 \% \leq \mathrm{PWI} \leq 35 \%$ with an ideal time of $30 \%$. This indicates that during the learning activities for each meeting, student activities are more dominant in recording teacher explanations, taking notes from books or from friends, solving problems on worksheets, summarizing group work.

The proportion of time students read books (student books and other sources) was $18.3 \%$ of the time available for each meeting. The percentage of time this activity is still within the ideal time tolerance interval specified. Likewise, the percentage of active listening / paying attention to teacher / friend explanations was $24.4 \%$ in the ideal time tolerance interval set.

Based on the results of the research that has been obtained, there are several field research findings concerning the difficulties in understanding the concepts and creative thinking processes of students by first analyzing the answers to the students' mathematical creative thinking abilities. The synthesis of the results of the error analysis and the analysis of the difficulties of the students' mathematical creative thinking process obtained useful research findings for further discussion. In the ongoing process of creativity, at the stages of the students 'mathematical creative thinking process according to the stage at the Wallas stage, the difficulties of students' mathematical creative thinking processes are obtained as follows:

\section{Preparation Stage}

The first stage, namely the preparatory stage where a person prepares to solve problems by learning to think, looking for answers, asking people and so on. At this stage ideas come and arise from a variety of possibilities. However, the idea takes place with the presence of a certain skill, expertise, or knowledge as the background or source from which it was born even though it still has to be given scaffolding. At this stage, there are no difficulties in the mathematical creative thinking process, marked by the absence of difficulties in facts and concepts which include the ability to remember names, symbols / symbols technically; the ability to express the meaning of a term that represents a particular concept; the ability to classify objects as instances of objects that are not examples. 


\section{Incubation Stage}

At the incubation stage, it is indicated that there are activities to find and collect data/information. The incubation stage is the stage where the individual seems to temporarily escape from the problem, in the sense that he does not think about the problem consciously but incubates it in a conscious realm. In the development of this stage, there is an understanding or maturity of the ideas that arise. Various techniques of refreshing and raising awareness such as meditation, creativity-enhancing exercises are carried out for the expansion and deepening of ideas. At this stage, the difficulties of the mathematical creative thinking process are also characterized by difficulties in principles and procedures which include the inability to plan solutions; inability to carry out discovery activities; the inability to abstract patterns.

\section{Illumination Stage}

The illumination stage is the stage where insight arises, when new ideas emerge, along with the psychological process that initiates and follows the emergence of new ideas/inspiration. At this stage there is communication of the results with people who are significant to the inventor, so that the results achieved can be refined again. At this stage, the difficulties of the mathematical creative thinking process are also marked by the difficulty of principles and procedures which include the inability to express their meaning and the inability to apply the principles.

\section{Verification Stage}

The verification stage or the evaluation stage is the stage where the new idea or creation must be tested against reality. The refinement of the embodiment of responsibility for results becomes the final stage of this process. Dimensions of the embodiment of creative work to be passed on to others after improvement and refinement. At this stage, the difficulties of the mathematical creative thinking process include the inability to provide many ideas, the inability to solve problems from different points of view, the inability to solve problems on their own, and the inability to develop or describe in detail a situation.

Based on the research findings, students have understood facts and concepts but have not yet fully understood the principles of mathematics. Other factors that also affect the difficulty of students' mathematical creative thinking processes are motivation and curiosity. Student motivation can also be supported by the attention of parents as a form of (informal) family education that supports formal education in schools. In this case it also strengthens support for the teacher as a facilitator and motivator. It was also found that they were still constrained by the lack of detailing and had doubts about the results of the work so that they had to be given a lot of scaffolding so that there were not many works that might be wrong or even empty. With inability to understand mathematical procedures and even inability to elaborate, it will reduce self-confidence in working on students' mathematical creative thinking problems.

This study focuses on the analysis of the difficulty of understanding the concepts and creative thinking processes of students by basing one of the main objectives in learning, namely training students' mathematical creative thinking processes. Framework for Action (2016) states that “.... Education 2030 will ensure that all individuals acquire a solid foundation of knowledge, develop creative and critical thinking and collaborative skills and build curiosity, courage, resilience", which means that Education 2030 will ensure that all individuals get a solid foundation of knowledge, develop creative thinking and critical and collaborative skills and builds curiosity, courage, resilience.

As Sophonhiranraka, et al (2014) conducted a literature review that focused on research from 2004 to 2014 by searching for more than 110 research studies related to 
creative problem solving. In addition, the learning objectives through the 2013 Curriculum must be able to think at a high level or often called HOTS (Higher Order Thinking Skils) which includes 4C, namely Collaborative, Comunicative, Critical, and Creative. By getting used to creative thinking, especially in mathematics, a good level of thinking can be achieved, thereby reducing student learning difficulties.

Vygotsky (Rusman, 2011) believes that social interactions with other friends spur the formation of new ideas and enrich students' intellectual development. Furthermore, Vygotsky (Arends, 2008) believes that intellectuals develop when they try to overcome the discrepancies generated by these experiences. In this experience, the individual connects new knowledge with previous knowledge and constructs new meanings. Besides emphasizing social interaction, in problem-based learning the teacher can also play an active role in providing assistance to students (scaffolding). Bruner (in Arends, 2008: 48) emphasizes the importance of helping students to understand the structure or key ideas of a discipline. The needs and active involvement of students in the learning process and true beliefs occur through personal discovery. Thus, students' mathematical creative thinking skills will be more easily developed to become a culture according to 21 st century learning that is communicative, collaborative, critical, and creative.

In the learning process that was carried out during 2 meetings in the class of SMA Angkasa 1 Lanud Soewondo that student activity was getting better after the application of problem-based learning learning models compared to previous learning which still used conventional learning in the form of lectures or explaining theory only. While learning emphasizes student-centered learning models, it is also necessary that students' mathematical creative thinking skills can be trained, accustomed to, and cultured properly through interactions between students and teachers. To be able to think creatively well, students must be at the level of development of formal operations so that they are able to think abstractly.

In collecting data on students' active activities in the class, it was carried out on several students in groups for each meeting. The largest proportion of the time students spend during teaching and learning activities is taking notes on teacher explanations, taking notes from books or from friends, solving problems at the LKPD, summarizing group work, namely with a percentage of $29.6 \%$ of the time available for each meeting. The percentage of time students read books (student books and other sources) was $18.3 \%$. The percentage of active listening / paying attention to teacher / friend explanations is $24.4 \%$. The percentage of student activity discussing / asking questions between students and their friends and between students and teachers is $27.3 \%$. The percentage of activity time doing something that is not relevant to learning is $0.4 \%$. The overall percentage of student activity is still at the ideal time tolerance interval set. From all active student activities, it can be concluded that student activities are in the effective category because all the criteria given are met in the learning activities that have been implemented. This is in line with Bruner's learning theory (Dahar, 1988) which states that learning concepts is done through active (enactive) action.

Based on the level of creative thinking ability of students who are dominated by students with moderate abilities. In addition, only two students who have a very high level of creative thinking skills and six students who have a high level of creative thinking skills. In addition, the results of the students 'answers related to the students' mathematical creative thinking test answers given were not overall good. This is because students are still not used to doing questions that lead to mathematical creative thinking.

Furthermore, data triangulation was carried out in order to obtain the results of the analysis of the difficulties of the students' mathematical creative thinking process. After 
analyzing the students 'mathematical creative thinking difficulties, the results of the research and observation of students' answer sheets with very high abilities were obtained as follows:

- From the fluency indicator (fluency), students are quick to understand the problems or problems that exist so that good, smooth, and effective solutions emerge and there is no difficulty in the creative thinking process of their students.

- From the flexibility indicator, students are quick to understand the problems or problems that exist so that various ideas emerge and there is no difficulty in the creative thinking process of their students.

- From the indicators of originality (authenticity), students are quick to understand the problems or problems that exist so that the ability to solve new things appears for students and there is no difficulty in the creative thinking process of their students.

High-ability students are discussed as follows:

- From the student fluency indicator, students are quick to understand the problems or problems that exist so that good, smooth, and effective solutions emerge and there is no difficulty in the creative thinking process of their students.

- From the flexibility indicator, students are quick to understand the problems or problems that exist so that various ideas emerge and there is no difficulty in the creative thinking process of their students.

- From the originality indicator (authenticity), students are quick to understand the problems or problems that exist so that the ability to solve new things for students appears and there is no difficulty in their students' mathematical creative thinking processes.

This is in line with Sagala's (2014) research, that the trajectory of creative thinking abilities possessed by students with high ability indicators is that students are able to understand a given problem, think about various mathematical concepts related to problem solving given, compound thinking (using various methods), use the results of thoughts to solve problems, review / review the results of solving problems that have been obtained, and add the necessary ways to solve mathematical problems.

Students with abilities are being discussed as follows:

- From the fluency indicator (fluency), students still do not understand the problems or problems that exist so that the solutions are not good and they are not able to work on the questions smoothly so they do not have the ability to think mathematically creatively characterized by the difficulty of students' mathematical creative thinking processes in understanding mathematical procedures. .

- From the indicator of flexibility (flexibility) students still do not understand the problems or problems that exist and have not been able to work on questions in a different way so that they do not have the ability to think mathematically creatively characterized by the difficulty of students' mathematical creative thinking processes in understanding mathematical procedures.

- From the elaboration indicator (details) students still do not understand the problems or problems that exist and are not able to detail the solution and do not have the ability to think mathematically creatively characterized by the difficulty of their students' mathematical creative thinking processes in understanding mathematical procedures.

This contradicts the results of Sagala's (2014) study, especially for the medium level mathematical creative thinking ability. He added that the trajectory of creative thinking abilities possessed by students with moderate ability indicators is that students are able to understand the problems given. Even though in this research students are less able to 
understand the problem. In this case, it is also affected because the level of creative thinking of students as stated by Sagala (2014) only includes three levels, namely low, medium, and high. Whereas in this study it consisted of very low, low, medium, high, and very high.

Low-ability students are discussed as follows:

- From the fluency indicator (fluency), students still do not understand the problems or problems that exist so that a good solution has not yet appeared, are not able to work on the questions smoothly so they do not have the ability to think mathematically creatively characterized by difficulties in their students' mathematical creative thinking processes in understanding mathematical procedures .

- From the indicator of flexibility (flexibility) students still do not understand the problems or problems that exist and have not been able to work on questions in a different way so that they do not have the ability to think mathematically creatively characterized by the difficulty of students' mathematical creative thinking processes in understanding mathematical procedures.

- From the indicators of originality (authenticity) students still do not understand the problems or problems that exist and do not have the ability to think mathematically creatively characterized by the difficulty of students' mathematical creative thinking processes in understanding mathematical procedures.

So, the difficulty in the mathematical creative thinking process in this study is the difficulty in applying principles and solving verbal problems along with the inability to detail problem solving which is characterized by difficulties in principles and procedures which include the inability to plan solutions; inability to carry out discovery activities; inability to abstract patterns, inability to express meanings and unable to apply principles. In addition, there is an inability to provide many ideas, inability to solve problems from different points of view, inability to solve problems on their own, and inability to develop or describe in detail a situation. Meanwhile, the understanding of mathematical facts and concepts is good. This is indicated by the absence of difficulties in facts and concepts which include the ability to remember names, symbols / symbols technically; the ability to express the meaning of a term that represents a particular concept; the ability to classify objects as instances of objects that are not examples.

\section{Conclusion}

The Based on the results of data analysis and discussion in this study, the following conclusions are stated:

1. The level of conceptual understanding and creative thinking skills of 21 students with 'very low' creative thinking skills as much as $14 \%$, 'low' creative thinking skills as much as $14 \%$, 'medium' creative thinking skills as much as $43 \%$, creative thinking skills' high 'by $19 \%$, and' very high 'ability to think creatively at $10 \%$.

2. After the student's answer process is described, it is concluded that students have prepared themselves to solve problems by learning to think, looking for answers, asking people and so on (preparation stage), searching and collecting data / information (incubation stage) giving rise to new ideas ( the illumination stage), until the worksheet is filled in correctly and the learning runs smoothly (verification / evaluation stage).

3. Analysis of the difficulty of understanding the concept and process of creative mathematical thinking of this research is the difficulty in applying principles and solving verbal problems along with the inability to detail problem solving which is 
characterized by difficulties in principles and procedures which include the inability to plan solutions; inability to carry out discovery activities; inability to abstract patterns, inability to express meanings and unable to apply principles. In addition, there is an inability to provide many ideas, inability to solve problems from different points of view, inability to solve problems on their own, and inability to develop or describe in detail a situation. Meanwhile, the understanding of mathematical facts and concepts is good. This is indicated by the absence of difficulties in facts and concepts which include the ability to remember names, symbols / symbols technically; the ability to express the meaning of a term that represents a particular concept; the ability to classify objects as instances of objects that are not examples.

4. The overall percentage of students' active activities used during teaching and learning activities is at the ideal time tolerance interval set.

Learning mathematics through a problem-based learning model needs to be cultivated to instill active individual and group awareness and develop students' mathematical creative thinking skills. The implementation of learning also provides the ability to understand mathematical facts and concepts. Developing learning with an understanding of mathematical objects and being involved through the creative mathematical thinking process provides opportunities for students to explore various aspects of fluency, flexibility, originality, and elaboration.

\section{References}

Arends, L. R. 2008. Learning to Teach. Yogyakarta: Pustaka Pelajar.

Baker, C. M. 2007. Evaluating the impact of Problem-based Leaning in Learning Style of Master's Students in Nursing Administrasion. Procedia: Journal Professional Nursing. Volume 2, Issue 4, 2007, pp: 214-219.

Dahar, R.W. 1988. Teori-Teori Belajar. Erlangga. Jakarta.

Erdogan, T. 2009. The effect of the Van Hiele Model Based instruction on the Creative Thinking Levels of 6th Grade Primary School Students. Educational Sciences: Theory \& Practice. 9 (1), Winter 2009, pp: 181-194.

Fahradina, N. 2014. Peningkatan Kemampuan Komunikasi Matematis dan Kemandirian Belajar Siswa SMP dengan Menggunakan Model Investigasi Kelompok. Jurnal Didaktik Matematika. Vol. 1, No. 1, September 2014, pp: 54-64.

Fitri, S., \& Zahari, C.L. 2019.- The implementation of blended learning to improve understanding of mathematics\|, The Sixth Seminar Nasional Pendidikan Matematika Universitas Ahmad Dahlan 2018: IOP Conf. Series: Journal of Physics: Conf. Series 1188 (2019) 012109, 2018, doi:10.1088/1742-6596/1188/1/012109.

Fitri, S., Syahputra, E., \& Syahputra, H. 2019. "Blended Learning Rotation Model of Cognitive Conflict Strategy to Improve Mathematical Resilience in High School Students", International Journal of Scientific \& Technology Research, vol.1, no. 1.

Framework for Action. 2016. Education 2030 Incheon Declaration and Framework for Action. Republic of Korea: Unesco. 2016.

Hudojo, H. 2001. Pengembangan Kurikulum dan Pembelajaran Matematika. Malang: Universitas Negeri Malang.

Imelda, and Anzelina, D. (2020). Students' Activities in Learning with Problem Based Learning Based Module to Enhance Students' HOTS on the Subject of Straight Line Equatiations. Budapest International Research and Critics in Linguistics and Education (BirLE) Journal Vol 2 (4): 552-559. 
Khairani, S., Suyanti, R.D., Saragi, D. (2020). The Influence of Problem Based Learning (PBL) Model Collaborative and Learning Motivation Based on Students' Critical Thinking Ability Science Subjects in Class V State Elementary School 105390 Island Image. Budapest International Research and Critics in Linguistics and Education (BirLE) Journal Vol 3 (3): 1581-1590.

Marliani, N. 2015. Peningkatan Kemampuan Berpikir Kreatif Matematis Siswa Melalui Model Pembelajaran Missouri Mathematics Project (MMP). Journal Formatif 5(1): 2015, pp: 14-25.

Munahefi, D.N. 2017. Analysis of Creative Mathematic Thinking Ability in Problem Based Learning Model Based on Self-Regulation Learning. IOP Publisihing Series 983 (2017), pp: 1-5.

Nasution, T. K. 2017. An Analysis of Syudent's Mathematical Creative Thinking Ability Senior High School on Geometry. IJARIIE - ISSN(O) - 2395 - 4396. Vol - 3 Issue - 2 2017, pp: 3860-3866.

Navarrete, C. Cesar. 2013. Creative Thinking in Digital Game Design And Development: A Case Study. Elsevier: Computers \& Education 69 (2013), pp: 320-331.

Nurqolbiah, S. 2016. Peningkatan Kemampuan Pemecahan Masalah, Berpikir Kreatif, dan Self-Confidence Siswa Melalui Pembelajaran Berbasis Masalah. JP3M: Jurnal Pendidikan dan Pengajaran Matematika. Vol. 2, No. 2, September 2016, pp: 143-158.

Permendikbud Nomor 58 tahun 2014. Tentang Kurikulum 2013 Sekolah Menengah Pertama/Madrasah Tsanawiyah.

Purba, E. P. 2017. Analysis of the Difficulties of the Mathematical Creative Thinking Process in the Application of Problem Based Learning Model. Advances in Social Science, Education and Humanities Research, volume 104, pp: 265-268.

Rahmazatullaili. 2017. Kemampuan Berpikir Kreatif dan Pemecahan Masalah Siswa Melalui Penerapan Model Project Based Learning. Beta: Jurnal Tadris Matematika. Vol. 10, No. 2 (November) 2017, pp: 163-183.

Romberg \& Fennema. 2009. Mathematics Classrooms That Promote Understanding. New Jersey: Lawrence Erlabaum Associates, Publisher.

Rusman. 2011. Model-Model Pembelajaran Mengembangkan Profesionalisme Guru. Jakarta: PT. Rajagrafindo Persada.

Sagala, S. 2014. Konsep dan Makna Pembelajaran. Bandung: Alfabeta.

Saragih, S. \& Habeahan, W. L. 2014. Journal of Education and Practice. Department of Mathematics, Science Faculty, State University of Medan, Vol. 5 No. 35.

Savery, R.J 2006. Overview of Problem based-learning: Definition and Distinction. The interdisciplinary Journal of Problem Based Learning, 1 (1); 9 - 20.

Simanjuntak, L.Y.A., Perangin-Angin, R.B., and Saragi, D. (2019). Development of Scientific Based Learning Video Media Using Problem Based Learning (PBL) Model to Improve Student Learning Outcomes in 4Th Grade Students of Elementary School Parmaksian, Kab. Toba Samosir. Budapest International Research and Critics in Linguistics and Education (BirLE) Journal Vol 2 (4): 297-304.

Sinaga, B. 2007. Buku Model PBM-B3. Surabaya: PPs Universitas Negeri Surabaya.

Siswono, Y., E., T.. 2004. Identifikasi Proses Berpikir Kreatif Siswa dalam Pengajuan Masalah (Problem Posing) Matematika Berpandu dengan Model Wallas dan Creative Problem Solving (CPS). Buletin Pendidikan Matematika Volume 6 Nomor 2.

Siswono. 2004. Model PBI Untuk Mengembangkan Pemahaman Mahasiswa Dalam Memecahkan Masalah Tentang Integral Tentu. Jurnal Peluang. Volume I Nomor 2 April 2013.

Sophonhiranraka, Samoekan, dkk. 2014. Factors Affecting Creative Problem Solving in 
the Blended Learning Environment: a Review of the Literature. Procedia Social and behavioral Sciences. 174(2015) 2130 - 2136. Thailand: Sukhothai Thammathirat Open University.

Syahputra, E. \& Surya, E. 2014. The Development of Problem Based Learning Model to Construct High Order Thinking Skill Students' on Mathematical Learning in SMA/MA. Journal of Education and Practice. Vol. 5, No. 39, 2014, pp: 52-55.

Tan, C. P. 2015. To What Extent does Problem Based Learning Contribute to Students' Professional Identity Development?. Elsevier: Teaching and Teacher Education. Vol 54, Februari (2016), pp: 54-56.

Trianto. 2011. Mendesain model pembelajaran inovatif - progresif. Jakarta : Kencana.

Widdiharto. 2008. Diagnosis Kesulitan Belajar Matematika dan Alternatif Proses Remidinya. Yogyakarta: PPPPTK Yogyakarta.

William, J. C.\& Paltridge, D. J. 2016. What We Think We Know about the Tutor in Prolem Realistik mathematic education. Australia: Elsevier LTd. 